\title{
Ending Rape in War: How Far Have We Come?
}

\author{
Lucy Fiske \\ University of Technology Sydney \\ Rita Shackel \\ University of Sydney
}

\begin{abstract}
The rape of women has for centuries been an endemic feature of war, yet perpetrators largely go unpunished. Women were sanctioned as the spoils of war in biblical times and more recently it has been claimed that it is more dangerous to be a woman than a soldier in modern conflict. Nevertheless, until the establishment of the ad hoc International Criminal Tribunals for Rwanda and the former Yugoslavia, there was very little concern regarding the need to address the rape of women in conflict. This paper briefly maps historical attitudes towards rape in war, outlines some analyses and explanations of why rape in war occurs and finally turns more substantively to recent efforts by the international community to prosecute rape as a war crime and a crime against humanity. We argue, that while commendable in some ways, contemporary approaches to rape in war risk reinforcing aspects of women's status which contribute to the targeting of women for rape and continue to displace women from the centre to the margins in debates and practices surrounding rape in both war and peace time. We conclude by arguing that criminal prosecutions alone are insufficient and that, if we are to end the rape of women and girls in war (and peace), we need a radical restructuring of gender relations across every sphere of social and political life.
\end{abstract}

\section{Introduction}

Rape of women has long been an endemic feature of war. For centuries, perpetrators of sexual attacks during conflicts have enjoyed effective impunity. Public narratives of war tend to focus on the victories and defeats of military troops or perhaps on the impacts on a degendered civilian population, such as displacement or death as ‘collateral damage’ (Palmieri et al. 2012, pp. 10-13; Henry 2011, p. 20; Puechguirbal 2012, p. 140). Until very recently, the ways in which conflicts impact on women in particular received very little attention. At least since the International Criminal Tribunals for Rwanda and Yugoslavia, there is a growing awareness and concern in both public consciousness and among legal and political leaders, of the extent and need to address the rape of women in war. The incidence of rape in war is such (C) 2014 Lucy Fiske and Rita Shackel. This is an Open Access article distributed under the terms of the Creative Commons Attribution 4.0 Unported (CC BY 4.0) License (https://creativecommons.org/licenses/by/4.0/), allowing third parties to copy and redistribute the material in any medium or format and to remix, transform, and build upon the material for any purpose, even commercially, provided the original work is properly cited and states its license. 
that Major General Patrick Cammaert, former Commander of the UN Peacekeeping operations in Democratic Republic of Congo (DRC) in 2008, declared that '[i]t is now more dangerous to be a woman than to be a soldier in modern conflict' (Chaikel 2011).

An estimated 25 - 50,000 Bosnian women and girls were raped in the Bosnian war from 1991 - 1995 (Chaikel 2011). In a landmark study of 68 victims of this abuse Loncar et al. (2006, p. 71) reported that of these women, 44 were raped more than once and 21 were raped daily during their captivity. Most of the rapes (96\%) were also accompanied by physical torture. Between 250,000 and half a million women and girls were raped during the 1994 genocide in Rwanda; Special Rapporteur on Rwanda Rene Degni-Segui remarked in 1996 that '[r]ape was the rule, and its absence the exception’ (UN Special Rapporteur 1996, p.16). In the Nanking Massacre of 1937 during the Second Sino-Japanese War somewhere between 20,000 and 80,000 women and girls were raped (Williams 2014). A 2011 study conducted by scholars at Harvard School of Public Health estimated that 48 rapes took place every hour in the DRC, this translates to 1,152 women raped every day (Peterman et al. 2011, p. 1060).

It is difficult to establish accurate statistics on the incidence of rape in conflict for a range of social and methodological reasons including the widespread under-reporting of rape due in no small part to social stigma attached to the status 'raped woman' and the collapse of social infrastructure which would ordinarily assist in the collation of such information, such as health services, police, courts, and psychosocial services (Palmieri et al. 2012, 13-14). Argument around the accuracy of rape statistics, however, is a diversion which obscures the lived experiences of women and the catastrophic effects that rape has. For example in the Bosnian study by Loncar et al. (2006) noted above, most of the women revealed psychological trauma. The most frequent psychological symptoms were depressiveness, avoidance of thoughts or conversations associated with trauma, and suicidal ideas. None of the women in this study had a psychiatric history before the rape, but at the time of the study, over 76\% suffered from depression, 75\% from social phobia, almost a third from posttraumatic stress disorder and a quarter of the women in the study had sexual dysfunctions. The link between militarisation and rape is clear (Henry 2011), but focusing on the number of rape victims also diverts attention away from the more important questions of ' why does a rise in militarism bring with it a rise in rape?' And 'how can we stop rape in war?' 
This paper briefly maps historical attitudes towards rape in war, outlines some analyses and explanations of why rape in war occurs and finally turns more substantively to recent efforts by the international community to prosecute rape as a war crime and a crime against humanity. Drawing on academic and legal sources as well as our own empirical work in the Great Lakes region of Africa we argue, that while commendable in many ways, contemporary approaches to rape in war risk reinforcing aspects of women's status which contribute to the targeting of women for rape and continue to displace women from the centre to the margins in debates and practices surrounding rape in both war and peace time. We conclude by arguing that criminal prosecutions alone are insufficient and that, if we are to end the rape of women and girls in war (and peace), we need a radical restructuring of gender relations across every sphere of social and political life.

Mainstream and high-level political and juridical concern about rape in war is a very recent phenomenon. Hagay-Frey (2011) identifies three historical phases in international law’s approach to rape of women: the 'Era of Silence' (prior to the Geneva Conventions of 1949), the 'Era of Honor' (from 1949 to the mid 1990s) and the 'Third Era' (from the prosecutions of rape in the International Criminal Tribunals of Yugoslavia and Rwanda in the late 1990s). Historically, the rape of women by victorious soldiers has been sanctioned as the 'spoils of war', fairly won in battle. The Bible for example, albeit historically contestable in parts, contains several tracts which sanction raping women as the 'spoils of war.' For example, in Zechariah 14: 1-2 (cited in Turano 2011, 1047) it is stated that:

Behold, a day is coming for the Lord when the spoil taken from you will be divided among you. For I will gather all the nations against Jerusalem to battle, and the city will be captured, the houses plundered, the women ravished...

Numbers 31: 17:18 states:

Now therefore, kill every male among the little ones, and kill every woman who has known man intimately, but all the girls who have not known man intimately, spare for yourselves. (cited in Turano 2011, p. 1047)

Analogous sanctions are found in the Koran. In Koran 3.50 it is stated:

O Prophet! Lo! We have made lawful unto thee the wives unto whom thou hast paid their dowries, and those whom thy right hand possesseth of those whom Allah hath given thee as spoils of war. (cited in Turano 2011, p. 1047) 
Attitudes to rape in war have progressed considerably over the last two centuries, moving from sanctioning of rape, through to official prohibition but little enforcement, to a recent trend towards prosecution. In 1863 Abraham Lincoln made rape by Union soldiers an offence punishable by death. Prohibitions against the violation of 'family honour' are found in the Hague Convention (1907) and the Geneva Conventions (1949). Despite these legal prohibitions however, there has been widespread political and popular silence around rape (Palmieri et al. 2012, Puechguirbal 2012, Snyder et al. 2006). The deep-rooted religious and historical sanctioning of rape continues to echo through the ages underpinning a fatalism that tacitly accepts the practice as an unfortunate, but natural and inevitable side effect of war ('boys will be boys').

There is also an argument to be made that to acknowledge rape in war poses a risk to 'higher order' goals and the protection of the nation and polity: exposing the rape of women and girls unsettles nationalist narratives of the soldier as hero, the selfless and innocent defender of the nation and its values (Henry 2011, p. 20). Despite extensive evidence of sexual offences during World War II, there were no prosecutions at Nuremberg, and only peripheral mentions of rape, subsumed under the larger category of 'atrocities' in the International Military Tribunal for the Far East (Hagay-Frey 2011, p. 62). Asia’s ‘comfort women’ are to this day still seeking acknowledgement and justice for their sexual enslavement (Arakawa 2001).

Rape and other forms of sexual violence such as forced marriage, enforced prostitution, sexual humiliation and forced pregnancy committed in war time were first prosecuted in the International Criminal Tribunal for Former Yugoslavia (ICTY) and the International Criminal Tribunal for Rwanda (ICTR), despite the fact that rape was not expressly mentioned in either statute governing these courts (O’Connor 2012). Rape is included in the Rome Statute (2002), establishing the International Criminal Court, as a war crime (Article 8), a crime against humanity (Article 7) and, in certain circumstances, as genocide (Article 6).

Moves by the international community both to legally prohibit and prosecute rape in war have been welcomed by many as an important step in confronting the culture of impunity surrounding rape in war and bringing an end to the practice (HRW et al. 2014). Some human and women's rights advocates hope that establishing women as legal subjects in international law will have a positive impact on women's standing in national jurisdictions, bringing consequent gains in women’s rights more broadly (Eaton 2003, UN ECOSOC 2003). There 
are however, questions regarding the efficacy of prosecutions to achieve these goals and a risk that celebrating successful prosecutions on the international stage may deflect attention away from a lack of progress in other areas such as enhancing women's safety in conflict and post-conflict environments and programs aimed at changing unequal power relations between men and women which arguably underpin violence against women.

\section{Why does Rape happen?}

The link between militarisation, war and rape of women and girls is irrefutable and well established (Henry 2011, Palmieri 2012, Brownmiller 1975, Hagay-Frey 2011), but it is important to ask the question 'why?' Why is rape so prevalent during many (but not all) conflicts? Why do men rape women in war time? There are many possible reasons advanced for this. First is the power of rape as a weapon of war to dishonour, demoralise and emasculate the enemy, which is well recognised (El-Bushra and Mukarubuga 1995, Meger 2010). Secondly, rape can occur with the intention of genocide, particularly in societies in which national and ethnic identity is patrilineal (Chesterman 1997; Snyder et al. 2006, p. 190). The deliberate impregnation of a community's women by the enemy disrupts the group's ongoing existence as a defined ethnic group. Rape is also sometimes used to terminate existing pregnancies - with the same intent of discontinuing ethnic bloodlines (Snyder et al. 2006). Thirdly, rape provokes terror. The widespread rape of women and the violence that accompanies such attacks affects whole communities acting to destabilize and disempower (Puechguirbal 2012). Fourthly, rape begets food insecurity. This occurs particularly in societies where women are responsible for working the fields, procuring food and water and collecting firewood. By raping women while they are working or collecting wood or water, the food supply for the entire community is disrupted (El-Bushra and Mukarubuga 1995). Moreover, in some sites, magic plays a role, some men have reported beliefs that raping women will cure them of AIDS, make them undefeatable in battle, or that they had been overcome by the devil or spirits and directed to rape (Lent Hirsch and Wolfe 2012). The rape of women may also be seen as a result of amplified gender roles in war time and an extension of pre-existing power relations and inequalities in many societies (Mazurana and Proctor 2013). Susan Brownmiller (1975, pp. 32-33) argues that rape during war is an extension of pre-existing misogyny:

War provides men with the perfect psychologic backdrop to give vent to their contempt for women. ... [War] confirms for men what they long suspect, that 
women are peripheral, irrelevant to the world that counts, ... war provides men with a tacit license to rape (1975, pp. 32-33).

A detailed discussion of all the varied reasons that may explain the phenomenon of rape in conflict is beyond the scope of this paper. In order however to probe further the question of why rape is used as a war strategy, we focus on the links between women as bearers of honour and on the amplification of particular and idealised gender roles during conflict.

\section{Honour, Nation and Gender}

Yuval Davis (1993, p. 627) argues that the 'nation' is an imagined community 'which divides the world between 'us' and 'them'" and which 'is maintained and ideologically reproduced by a whole system of ... symbolic 'border guards', with gender playing 'an especially significant role.' The territory on which a nation exists and upon which its members are born and depend for survival and for the reproduction of their collective national identity is imagined as feminine; the giver of life who must be defended by her sons ${ }^{1}$. The territory is feminised and the imagined ideals of the nation, its most sacred attributes are symbolically represented by the women of the nation (Yuval Davis 1993, Saigol 2012). 'Women often come to symbolize the national collectivity, its roots, its spirit, its national project. Moreover, women often symbolize national and collective 'honour' (Yuval Davis 1993, p. 627). Thus, in most societies, the category 'woman' is invested with powerful labels and symbolism. Women are reified as the mothers of the nation, bearers of ethnic or national identity and bearers of the group's honour. These reified ideals are problematic for women in peacetime, tightly circumscribing what is appropriate conduct for women (the policing of which is diffused as a sometimes sacred obligation amongst all members of society, making a woman's body and behaviour not entirely her own), with serious consequences for those who transgress.

However problematic such collectively held ideals of womanhood and honour may be in peacetime, such tropes tend to be amplified in war with profound implications for women in conflict and post conflict societies. Snyder et al. (2006, p. 188), in exploring possible roots of the systematic rape of women as a feature of the Yugoslav wars in the 1990s, identify a ‘rising tide of nationalism’ in which ‘women became popular symbols who both embodied

\footnotetext{
${ }^{1}$ Female symbols and language are evident in many nationalist discourses including Marianne of the French Revolution, Little Mother Serbia, Mother India, and the Mother Country (England).
} 
and marked the boundaries of the homeland in a nationalist discourse that conflated images of mothers with the nation itself'. Examples of images and narratives of women as essentialised symbols of nation and honour deployed to justify and fortify the nation's war effort - either as the worried, but essentially powerless mother/sister/daughter, or as the victim of a barbaric monstrous enemy can be found throughout history. Propaganda posters from World War Two are particularly illustrative of such discourses. Whilst such overt woman-nation-honour images are seldom seen today, similar discourses are nevertheless still easily found. For example, TIME Magazine's cover of the 9 August 2010 edition urging America and her allies to 'stay the course' in Afghanistan reveals the hegemonic tropes of idealised masculinity and femininity put to service in the war effort ${ }^{2}$.

These gender roles however are not spontaneously created at the outbreak of fighting, rather they are pre-existing and deeply embedded in patriarchal notions of the family, community and nation. When conflict erupts gender roles become narrowed and amplified. Hegemonic masculinity is aggressive, brave, conquering and powerful; whereas the corresponding femininity is the symbol of purity, the keeper of honour and home, the goodness worth fighting, killing and dying for. That these forms of masculinity and femininity may not be an accurate reflection of actual people matters not, for the hegemony needs simplicity and clarity, a clear demarcation of 'good' and 'evil' for it to mobilise into action (Mazurana and Proctor 2013).

The amplification of women's symbolic power elevates her value as a strategic target in war. And it is this honour, rather than the integrity of the woman as individual, autonomous legal subject which earlier prohibitions against rape in war sought to protect. The Hague Convention and the Geneva Conventions all articulate the prohibitions as a protection of 'family honour'. The commentary accompanying the Geneva Conventions explains that 'women ... have an absolute right to respect for their honour and their modesty, in short, for their dignity as women’ (cited in Chesterman 1997, p. 332), and in so doing, makes a woman's right to the protection of the law contingent upon the highly contextual and problematic notions of 'honour' and 'modesty'. Chesterman (1997, p. 332) argues that framing rape as an injury to honour 'mask(s) the violent nature of the crime' and 'is

\footnotetext{
2 The cover image can be viewed at http://content.time.com/time/covers/0,16641,20100809,00.html Accessed 20 September 2014
} 
contingent upon hierarchized gender relations that naturalise the experience of women as victims.'

Susan Brownmiller goes further, arguing that the rape of women in war is a form of communication between men and that the woman herself is incidental, a mere message board in the correspondence:

The body of a raped woman becomes a ceremonial battlefield, a parade ground for the victor's trooping of the colors. The act that is played out upon her is a message passed between men - vivid proof of victory for one and loss and defeat for the other (Brownmiller 1975, p. 38).

\section{Rape in International Criminal Law}

As noted above despite international law purporting to have long offered protection to women against rape and offences against their honour, rape was first prosecuted in the ICTY and ICTR. The Akayesu ${ }^{3}$ decision of the ICTR (handed down in Rwanda in September 1998) was revolutionary in several respects. Apart from being the first conviction for sexual violence against women on the international stage, it found that rape in the Rwandan genocide was used as part of a widespread and systemic attack and constituted genocide and a crime against humanity. It further developed a progressive definition of rape as 'a physical invasion of a sexual nature, committed on a person under circumstances which are coercive. ${ }^{4}$ This definition is crucial as it does not require the victim to demonstrate her/his non-consent, nor does it require that the perpetrator used threats or force, instead understanding the circumstances of conflict to constitute coercion. Finally, Akayesu was not personally accused of committing any rapes himself, but as a commander he was held responsible for rapes committed in and around his bureau communal and of sending 'a clear signal of official tolerance for sexual violence, without which these acts would not have taken place. ${ }^{5}$

The ICTY further developed jurisprudence on rape in war through several other decisions. Importantly it sought to establish more specific elements of the crime of rape and considered the issue of consent, stating that 'the true common denominator which unifies the various

\footnotetext{
${ }^{3}$ Prosecutor v. Akayesu, Judgment, Case No. ICTR-96-4-T, 2 September 1998. Akayesu was Mayor of Taba commune in Rwanda and was charged with multiple crimes against humanity and crimes of genocide.

${ }^{4}$ Akayesu judgment at 598. This definition of sexual violence was also later concurred with in the Prosecutor $v$ Kvocka et al., Case No. IT/98-30/1-T, 2 November 2005. For further analysis of ICTR and ICTY decision see for example Chesterman 1997, De Ruiter 2011, De Vito 2011, Hagay-Frey 2011 or Turano 2011.

${ }^{5}$ Akayesu Judgment at para 693.
} 
systems [of law] ... is the basic principle of penalising violations of sexual autonomy. ${ }^{6}$ On a more positive note however, it also extended liability of superior officers for the conduct of their soldiers to impose a duty for officers to proactively investigate 'in order to ascertain whether offences were being committed'?

While recent efforts to articulate and prosecute sexual crimes against women is a welcome departure from both euphemising sexual violence as an offence against a woman's honour (as offences are codified in the Geneva Conventions) and the historical reluctance to prosecute, there remain several concerns. We limit discussion here to three key points which by no means represents an exhaustive critique. First we argue that there are ongoing echoes of women as bearers of a group's honour; secondly that there is a legal focus on certain types of sexual violence to the exclusion of other types of sexual violence; thirdly that there is a privileging of criminal justice over physical, emotional, social and economic recovery for the woman.

\section{Echoes of honour}

While women appear before International Criminal Law (ICL) due to violations of their bodies and minds, rather than of her modesty or honour, a woman still does not appear as an autonomous rights bearing subject. As several scholars have persuasively argued, 'sexual violence is not in and of itself an international crime' (Grewal 2010, p. 75). In order to be a crime in international law, sexual violence must occur in specific contexts and circumstances. Chesterman (1997, p. 333) argues that the treatment of sexual violence in international law 'impos(es) a definition that depends not on experience but on the legally validating circumstances in which that experience obtains a context'. He goes on to argue that 'the legal response to rape in war' is based on 'the effacement of the feminine subject, and her selective appropriation into the discourse of war crimes as the bearer of essentialized feminine virtues (protecting men's interests in "their" women)' (Chesterman 1997, p. 332). Kirsten Campbell concurs, noting that International Criminal Law, for all its progressive developments continues to misunderstand the atrocity of rape at a fundamental level by continuing to treat it as significant 'only where it is understood in terms of a crime against a victim's community or nation' (cited in Grewal 2010, p. 76).

\footnotetext{
${ }^{6}$ Prosecutor v. Dragoljub Kunarac, Radomir Lovac and Zoran Vukovic (Trial Judgment), Case No. IT-96-23-T and IT-96-23/1-T, 22 February 2000 at para 440.

${ }^{7}$ Prosecutor v. Naser Oric (Trial Judgement). Case No. IT-03-68-T. 30 June 2006 at para 322.
} 
Although the terminology of 'honour' has been expunged, women's experiences of sexual violence continue to be interpreted through national, communal and predominantly patriarchal lenses. The effects this has are multiple and profound. Rather than radically delinking women and honour, modern ICL has potentially reinforced women becoming visible in the high status public sphere of international law through her ethnic or national identity rather than her gender identity, even though it may be her gender that is primarily determinative in terms of her life experiences in both war and peace. ICL has also arguably created a new role for women to play in service of the nation - that of testifying at international tribunals about the victimisation of her national or ethnic group and the criminality and barbarity of the 'other side’ (Mertus 2004).

The raped woman witness is of great value during the trial, but if patriarchal constructions of womanhood remain uncritiqued, she returns not as 'national hero', but instead takes up her position as a 'raped woman'; sullied, without honour and of little or no value in future life. Redress Africa, a British based NGO, interviewed several Rwandan women who had testified about sexual violence at gacaca (the domestic special courts set up to respond to the mass violence of the genocide). One woman complained that 'Wherever I went, people mocked and made fun of me. It affected me so much that I became sick and remained bed-ridden for a long time’' (Redress 2008, p. 88).

This corresponds with interviews we conducted with women in DRC in April 2014 as part of a research project exploring women's experiences of justice following mass violence ${ }^{8}$. Many of the women we spoke with recounted trying to hide their rape from husbands and communities for fear of being abandoned and stigmatised, a fear which was sadly realised for many:

I remember before being raped that my health was very fine and I had sufficient means. After rape, my husband left me. ... I am unable to do anything by myself. Even if he comes, I am unable to satisfy his needs, so I am nothing in the society. (41 year old woman, mother of seven children, 22 April 2014, Rutshuru, DRC)

\footnotetext{
${ }^{8}$ The research project is an Australian Aid funded project in partnership with the authors and Action Aid Australia, Uganda, DRC and Kenya titled Making Transitional Justice Work for Women: Rights, Resilience and Responses to Violence Against Women in northern Uganda, Kenya and Democratic Republic of Congo. For more see www.justiceforwomen.net.au.
} 


\section{Focus on certain types of sexual violence}

For rape to constitute a war crime, crime against humanity or genocide, the act of rape itself is insufficient, it must be committed in particular circumstances (such as during a genocide, an inter-ethnic war or other circumstance that enables the violence to come under ICL jurisdiction) or in the context of a particular relationship between the woman's and the perpetrator's ethnic or religious identities. The effect of this is that only certain types of rape can be prosecuted - those conducted by, or at the instruction of, a member of the enemy forces committed during a genocide or armed conflict. Women who are raped in circumstances that do not meet the legal definition, such as those raped by members of their own 'side', by peace-keepers or other actors in emergencies, gain no benefit from recent advances in ICL. This is a significant omission. In 2004 the UN launched an investigation into sexual assaults by peace-keepers in DRC, leading to the expulsion of 65 military personnel and 9 civilian staff of MONUC in 2005 (Fleshman 2005). Allegations have been made against UN peace keepers in Cambodia in the early 1990s and again in former Yugoslavia in the mid-1990s. In the early 2000s reports emerged of peace keepers and humanitarian workers seeking sexual favours from women and girls in exchange for food, water and medicine in refugee camps in Sierra Leone, Guinea and Liberia. No charges were laid in any of these cases (Fleshman 2005). In northern Uganda the entire population was forced into IDP camps and a position of dependency on UPDF soldiers and humanitarian agencies for the necessities of life. Here too, stories of 'survival sex'; when women 'consent' to sex with those in positions of power in exchange for food, water, access to firewood, or protection against assaults by others, have been extensively recorded (Okello \& Hovil 2007).

Even in cases where the act may meet the elements of the definition, decisions to prosecute and on which charges are made according to a range of considerations. Although law as an institution and legal prosecutions of rape draw upon a narrative of concern for women, women's experiences and desires are often relegated to secondary concerns in prosecutorial decision making (Mertus 2004). Cases are chosen for their strategic value. Which are most likely to secure a conviction? Which will advance jurisprudence on an issue? Which are politically palatable? Which will develop the historical record in the 'right' manner? Political context, for example, was key in the inability of the Special Court for Sierra Leone to prosecute any sexual offences committed by the Civil Defence Forces (CDF), with the Trial 
Chamber ruling all evidence relating to sexual violence inadmissible. ${ }^{9}$ As one woman told researchers:

I feel so bad, because they raped me very brutally, and that was the main reason for going to court to testify. As soon as I got there, my lawyer told me that I should not talk about that anymore. And up to now, that still causes me pain. It makes me feel bad. (cited in Grewal 2010, p. 72)

Furthermore, it does not address the heightened levels of sexual and other violence that women experience before and after periods of conflict. Grewal (2010, pp. 75-76) argues that while the highly specific definitions of sexual crimes as international crimes is necessary for the law 'it is based on a fiction: that a clear distinction can be drawn between women's experiences in war and women's lives in peace.'

\section{Privileging of criminal justice over woman-centred recovery}

The recent enthusiasm for prosecutions of rape in conflict focuses attention and resources on legal responses to rape, rather than on direct efforts to prevent rape or to assist women to recover after the event. Our current qualitative research in DRC anecdotally accords with larger, quantitative studies (e.g. Bartels 2010) that women there are most commonly raped while in their homes at night, while working in the fields during the day or are abducted from either home or the fields and raped in captivity in the forest. With such a predictable pattern of risk identified, it is difficult not to have questions about the criteria for decision making about where protective forces are deployed and which targets attract priority status for protection.

The prosecution of rape in conflict is important and may yet deliver on its intended aim of ending impunity and bringing the practice to an end. However, practices entrenched across centuries, even millennia, will not be eradicated easily and we must approach this as a long term project. We must also approach the task holistically and keep women and their experiences at the centre of thinking and planning.

\footnotetext{
${ }^{9}$ The Lome Accord, which brought the conflict to an end grants amnesty to former combatants, reading at Article 3 'To consolidate the peace and promote the cause of national reconciliation, the Government of Sierra Leone shall ensure that no official or judicial action is taken against any member of the RUF/SL, ex-AFRC, exSLA or CDF in respect of anything done by them in pursuit of their objectives as members of those organisations...' (cited in Shocken 2002, p. 440). For further reading on prosecutions in the SCSL see for example Eaton 2003, Grewal 2010 and Shocken 2002.
} 
Courts and tribunals are expensive ventures to run. The ICTR operated with a biennial budget of $\$ 269,758,400$ for 2006 and 2007. In the same period, the ICTY operated at a cost of $\$ 276,474,100$. By October 2006 the ICTY had tried 51 cases and the ICTR 22 (Wippman 2006, p. 861). While significant attention and resources are directed to courts and tribunals; health, psychosocial, economic empowerment and community attitude programs are struggling. While juridical approaches to rape may focus on the elements of the event and conclude at the end of the rape, the legacy of rape reverberates throughout a woman's life in multiple ways long after the attack is over.

One of the questions we are currently asking in our research and interviews with women from DRC, Kenya and Uganda is 'what would justice look like for you?' Some women have talked of wanting to see the perpetrators of violence against them and others, prosecuted and jailed, or even killed, but the common responses focus on the need to recover. Women have talked of the need to heal their hearts, provide for their children, recover from the injuries and illnesses sustained during the rape and to establish economic independence.

\begin{abstract}
We need peace in our areas so that we may come back home and continue our former activities. In addition we need money to help children study or create schools for them. But the most important need is to take care of the victims both after rape and in case the perpetrator is captured. Actually by giving us sewing machines to become dress makers for the family to survive. But we notice the DRC government thinks capturing the perpetrator is sufficient whereas the victim is still suffering. (25 year old woman, mother of three children, 19 April 2014, Minova, DRC)
\end{abstract}

The conviction of the perpetrator is an important and necessary part of justice, but it is insufficient in itself. A woman-centred approach to justice for rape would look very different. The under-funding of woman-centred services is so chronic that one woman told us she was unable to complete an essential course of post-rape anti-HIV medication as the hospital supply was unable to keep pace with the rate of need: 'When I went there they missed the medicine saying that we are too numerous.' (27 year old woman, six children, 23 April 2014, Bweremana, DRC).

The focus on prosecutions also serves to obscure the catastrophic impact that rape can have on a woman's life. A woman's emotional pain and loss of a sense of safety in the world, her low social status, poor marriageability, economic precarity, chronic illnesses such as HIV, or injuries such as fistulas or maiming sustained during the attack, her abandonment by her 
husband or her becoming pregnant and then having a child born of rape are all excluded from the judicial process, yet it is precisely these issues that women in Kenya, DRC and Uganda are raising in interviews.

\section{Conclusion}

Rape is a scourge with wide-reaching and lasting effects for its victims. It is undoubtedly a practice which needs concerted attention aimed at prevention, prosecution and healing for survivors. Effective actions to end rape in war need to be based in multivariate understandings of the phenomenon, acknowledging the deep historical roots, contemporary power relations and social structures and contextualised critiques of rape's function in specific conflicts. The prosecution of rape in war in some ways marks a radical departure from previous responses, but must also be scrutinised for inadvertent effects such as the potential for reinforcing unhelpful gendered ideals and its approach to rape in war as exceptional, thereby reinforcing a delinking from sexual violence in peace and from other types of violence that women experience. If rape, in both war and peace, is to be effectively addressed we require a radical restructuring of gender relations in society. Women need to be freed from the burden of honour and recognised legally, politically and socially as autonomous rights bearing human beings in their own right. This task requires a more holistic approach engaging prosecutions, health, reparations, long term attitudinal change programs and community development approaches.

\section{References}

Chesterman, S. 1997, 'Never again... and again: Law, order, and the gender of war crimes in Bosnia and beyond', Yale Journal of International Law, vol. 22, pp. 299 - 343

De Ruiter, D. 2011, Sexual Offenses in International Criminal Law; Cases and documents, International Courts Association, The Hague.

De Vito, D. 2011, Rape, Torture and Genocide; Some theoretical implications, Nova, New York

Eaton, S. 2004, 'Sierra Leone: The proving ground for prosecuting rape as a war crime' Georgetown Journal of International Law, vol. 35, pp. 873-919

El-Bushra, J. and Mukarubuga, C. 1995, 'Women, war and transition', Gender and Development, vol. 3, no. 3, pp. 16-22. http://dx.doi.org/10.1080/741921866

Fleshman, M. 2005, 'Tough UN line on peacekeeper abuses. Action initiated to end sexual misdeeds in peacekeeping missions', Africa Renewal. (April 2005) Available at: http://www.un.org/africarenewal/magazine/april-2005/tough-un-line-peacekeeperabuses Accessed 28 August 2014 
Grewal, K. 2010, 'Rape in conflict, rape in peace: Questioning the revolutionary potential of international criminal justice for women's human rights', The Australian Feminist Law Journal, vol. 33, pp. 57-79. http://dx.doi.org/10.1080/13200968.2010.10854444

Hagay-Frey, A. 2011, Sex and Gender Crimes in the New International Law; Past, Present, Future, Martinus Nijhoff Publishers, Leiden. http://dx.doi.org/10.1163/ej.9789004189126.i-182

Henry, N. 2011, War and Rape; Law, memory and justice, Routledge, Abingdon.

Human Rights Watch (HRW), REDRESS, FIDH, TRIAL, ECCHR, Amnesty International (2014) Investigating and prosecuting sexual and gender-based violence as crimes under international law. Open Letter to the EU Genocide Network on Investigating and Prosecuting Sexual and Gender-Based Violence as Crimes under International Law. 16 May 2014. Available at: http://www.hrw.org/news/2014/05/16/lettermembers-eu-genocide-network-investigating-and-prosecuting-sexual-and-gender-b Accessed 16 December 2014.

Lent Hirsch, M. and Wolfe, L. 2012, 'Conflicts profile: Democratic Republic of Congo', Women Under Siege Project. Available at: http://www.womenundersiegeproject.org/conflicts/profile/democratic-republic-ofcongo\#reasons Accessed 19 September 2014

Loncar, M., Medved, V., Jovanovic, N. and Hotujac, L. 2006, 'Psychological consequences of rape on women in 1991-1995 war in Croatia and Bosnia and Herzegovina', Croatian Medical Journal, vol. 47, no. 1 pp. 67ff.

Meger, S. 2010, 'Rape of the Congo: Understanding sexual violence in the conflict in the Democratic Republic of Congo', Journal of Contemporary African Studies, vol. 28, no.2, pp. 119-135, http://dx.doi.org/10.1080/02589001003736728

Mertus, J. 2004, 'Shouting from the bottom of the well; The impact of international trials for wartime rape on women's agency', International Feminist Journal of Politics, vol. 6, no.1, pp. 110-128. http://dx.doi.org/10.1080/1461674032000165950

Mazurana, D, and Proctor, K, 2013, Gender, Conflict and Peace; An Occasional Paper, World Peace Foundation, Fletcher School, Tufts University, Boston.

O’Connor, V. 2012, Prosecution of Rape as a War Crime, International Network to Promote the Rule of Law (INPROL) July 2012 Available at: http://www.inprol.org/publications/prosecution-of-rape-as-a-war-crime Accessed 16 September 2014.

Okello, M C, and Hovil, L. 2007, 'Confronting the reality of gender-based violence in Northern Uganda’, International Journal of Transitional Justice, vol. 1, no. 3, pp. 433-443. http://dx.doi.org/10.1093/ijtj/ijm036

Palmieri, D., Branche, R., Horne, J., Lagrou, P., Virgili, F. and Delpla, I. 2012, 'Writing the history of rape in wartime', in Branche, R and Virgili, F. (eds.) Rape in Wartime, Palgrave Macmillan, London, pp. 153-168.

Peterman, A., Palermo, T. and Bredenkamp, C. 2011, 'Estimates and determinants of sexual violence against women in the Democratic Republic of Congo', American Journal of Public Health, vol. 101, no.6, pp. 1060-1067. http://dx.doi.org/10.2105/AJPH.2010.300070

Puechguirbal, N. 2012, 'Breaking the silence. New approaches to the consequences of rape in some African conflicts, 1994-2008' in Branche, R and Virgili, F. (ed.) Rape in Wartime Palgrave Macmillan, London, pp. 140-152.

Redress and African Rights 2008, Survivors and Post-Genocide Justice in Rwanda; Their experiences, perspectives and hopes, Redress and African Rights, London.

Saigol, R. 2012, 'Gendered Conflicts: A Feminist Perspective on Knowledge of Conflict', paper presented at the the XVIIth South Asian Feminist Capacity Building Course 
On Gender, Sustainable Livelihoods, Human Rights And Peace; 4 September- 4 October 2012, Dhulikhel, Nepal.

Shocken, C. 2002, 'The Special Court for Sierra Leone: Overview and recommendations', Berkley Journal of International Law, vol. 20, no. 2, pp. 436 - 461.

Snyder, C., Gabbard, W., May, D. and Zulcic, N. 2006, 'The battleground of women's bodies: Mass rape in Bosnia-Herzegovinia’, Affilia, vol.21, pp. 184-195, http://dx.doi.org/10.1177/0886109905286017

Turano, L. 2011, 'The gender dimension of transitional justice mechanisms', International Law and Politics, vol. 45, pp. 1045-1047.

UN Special Rapporteur to the Commission on Human Rights,1996, 'Report on the Situation of Human Rights in Rwanda' (E/CN.4/1996/68) at para 16, Available at: http://www1.umn.edu/humanrts/commission/country52/68-rwa.htm Accessed 16 September 2014.

Williams, K. 2014, ‘Conflicts Profile: Nanking', Women Under Siege Project, Available at: http://www.womenundersiegeproject.org/conflicts/profile/nanking Accessed 21 September 2014.

Wippman, D. 2006, 'The costs of international justice', The American Journal of International Law, vol. 100, no.4, pp. 861-881.

Yuval-Davis, N. 1993, ‘Gender and nation', Ethnic and Racial Studies, vol. 16, no.4, pp. 621632. http://dx.doi.org/10.1080/01419870.1993.9993800 